\title{
Analisa Faktor yang Mempengaruhi Minat Baca Mahasiswa PGSD
}

\author{
Atikah Mumpuni, Rizki Umi Nurbaeti \\ Universitas Muhadi Setiabudi \\ atikahmumpuni@gmail.com
}

\section{Sejarah Artikel}

diterima 29/10/2019

diterbitkan 13/12/2019

\begin{abstract}
This research was aimed to analyze and describe internal and external factors that influenced reading interest of Elementary School Teacher Education (PGSD) students, from students assessment themselves and also lecturer and librarian perception. This research used a qualitative approach. Data gathering technique used in this research was by data gathering comprised of documentation, observation and questionnaire. Data analysis model in this research followed a concept provided by Miles dan Huberman. The research result conclusion included: 1) internal factors that influenced students reading interest covered three things included feeling factor, attention and motivation; 2) external factors that influenced students reading interest covered three things included lecturer factor, environmental factor and facility factor; 3) factors that influenced students reading interest from lecturer and librarian perception covered curiousity, interested-topic factor, book availability factor and task factor. The implication of this research is the existence of foundation and accuracy of treatment when developing student reading interest.
\end{abstract}

Keywords: factor, reading interest, pgsd

\section{Abstrak}

Penelitian ini bertujuan untuk menganalisis dan mendeskripsikan faktor-faktor internal dan eksternal yang mempengaruhi minat baca mahasiswa Pendidikan Guru Sekolah Dasar (PGSD), dari penilaian mahasiswa sendiri, serta dari persepsi dosen dan pustakawan. Pendekatan yang digunakan dalam penelitian ini adalah pendekatan kualitatif. Teknik pengumpulan data yang digunakan dalam penelitian ini pengumpulan data terdiri atas dokumentasi, observasi, dan angket. Model analisis data dalam penelitian ini mengikuti konsep yang diberikan Miles dan Huberman. Simpulan hasil penelitian ini yaitu: 1) Faktor-faktor interen yang mempengaruhi minat baca mahasiswa meliputi tiga hal, faktor perasaan, perhatian, dan motivasi; 2) faktorfaktor eksteren yang mempengaruhi minat baca mahasiswa meliputi tiga hal, faktor dosen, faktor lingkungan, dan faktor fasilitas; 3) faktor-faktor yang mempengaruhi minat baca mahasiswa dari persepsi dosen dan pustakawan meliputi faktor rasa ingin tahu, faktor topik yang diminati, faktor ketersediaan buku, dan faktor tugas. Implikasi dari penelitian ini adalah adanya landasan dan ketepatan perlakuan saat akan mengembangkan minat membaca mahasiswa.

Kata Kunci: faktor, minat baca, pgsd 


\section{PENDAHULUAN}

Bahasa Indonesia sebagai bahasa pemersatu dan bahasa negara. Oleh sebab itu, bahasa Indonesia wajib untuk diajarkan dalam sekolah formal. Salah satu komponen utama pembelajaran bahasa berkaitan dengan keterampilan berbahasa. Keterampilan berbahasa tersebut meliputi keterampilan menyimak, berbicara, membaca, dan menulis. Selama ini pembelajaran keterampilan berbahasa tersebut baru menekankan pada keterampilan berbahasa. Belum mengembangkan minat terhadap keterampilan berbahasa itu sendiri, khususnya pada keterampilan membaca. Hal ini menngakibatkan masyarakat Indonesia mempunyai minat yang rendah terhadap membaca. Hal tersebut diperkuat dengan tulisan Amiranti (2017) bahwa berdasarkan data dari United Nations Educational, Scientific, and Cultural Organiztion (UNESCO) minat baca masyarakat Indonesia hanya $0,01 \%$, yang tentu sangat rendah jika dibandingkan dengan negara-negara lain. Najwa Sihab sebagai Duta Baca Indonesia menyebutkan dalam harian Tirto, bahwa dalam setahun, anakanak Eropa dan Amerika dapat membaca $25-27 \%$ buku, di Jepang anak-anak dapat membaca $15-18 \%$ buku.

Rendahnya minat baca masyarakat Indonesia juga sangat terasa di kalangan mahasiswa, khususnya pada mahasiswa di Program Studi Pendidikan Guru Sekolah Dasar (PGSD) Universitas Muhadi Setiabudi (Umus). Rendahnya minat baca tersebut dapat diindikasikan dari tugas-tugas yang dikerjakan, khususnya dalam pembuatan makalah. Referensi yang digunakan kebanyakan bersumber dari internet. Internet merupakan salah satu bentuk perkembangan tektologi informasi, akan mempermudah seseorang dalam mencari suatu informasi, sehingga akan dapat mengurangi minat baca mahasiswa. Hal tersebut diperkuat dengan hasil penelitian Siswati (2010) menyebutkan teknologi informasi yang maju, seperti internet akan mempengaruhi penurunan aktivitas membaca mahasiswa.

Rendahnya minat baca mahasiswa juga diindikasikan dari kurang disukainya soal-soal evaluasi yang berbentuk deskripsi panjang. Bahkan, banyak mahasiswa yang kurang memahami maksud soal, sehingga tidak mendapatkan hasil yang maksimal. Tidak hanya itu, minat baca mahasiswa yang masuk katagori rendah diindikasikan dari kualitas pertanyaan yang diajukan oleh mahasiswa. Pertanyaan-pertanyaan yang diajukan biasanya tidak mendalam, tidak kritis, bahkan seringkali jawabannya sudah ada dididalam slide atau materi yang disajikan. Hal ini tentu menunjukkan bahwa mahasiswa tidak mempersiapkan terlebih dahulu materi perkuliahan yang akan dipelajari dengan membaca berbagai referensi yang disediakan.

Mahasiswa perlu membaca untuk dapat memenuhi kebutuhannya, salah satunya untuk memenuhi tugas akademiknya. Membaca sendiri dilakukan melalui serangkaian proses menerjemahkan simbol tulis kedalam bunyi. Hal ini seperti yang dikemukakan oleh Patiung (2016) membaca adalah pengenalan simbol untuk menyusun bahasa sehingga mendapatkan informasi, termasuk hiburan. Simbol-simbol yang 
dimaksud mencakup huruf, rangkaian huruf, dan tanda baca. Membaca juga tidak terlepas dari aktivitas-aktivitas didalamnya. Aktivitas-aktivitas yang terjadi dalam proses membaca dilakukan untuk dapat memahami bahasa tulis. Hal ini seperti yang dikemukakan oleh Djuanda, Resmini, Indihadi (2006) bahwa membaca merupakan aktivitas proses dan produk dalam memahami bahasa tulis. Membaca sebagai proses mencakup aktivitas kompleks dan rumit seperti yang telah dijabarkan sebelumnya. sementara itu, membaca sebagai produk mengacu pada hasil yang diperoleh dari kegiatan membaca, misalnya memahami informasi, dsb.

Mahasiswa sebagai agen perubahan, tentu harus senang membaca. Membaca akan akan menjadikan mahasiswa unggul dalam segala bidang, seperti salah satu visi Universitas Muhadi Setiabudi. Hal ini karena, dari membaca, mahasiswa akan memeroleh banyak manfaat. Manfaat membaca dalam kehidupan sehari-hari menurut Taufina (2016) yaitu: 1) terbukanya wawasan; 2) adanya pemikiran baru; 3) meningkatkan kecerdasan dalam segala bidang; dan 4) meningkatkan kemandirian dalam mencari pengetahuan. Minat baca pada mahasiswa tidak tumbuh begitu saja, tetapi ada proses yang perlu dilewati. Didalam melewati proses itu, tentu ada banyak kendala yang harus diatasi. Putri \& Suyitno (2018)mengemukakan beberapa kendala dalam menumbuhkan kesenangan mahasiswa dalam membaca meliputi kendala fisik, intelektual, minat dan bakat, kebiasaan, dan beban belajar. Disamping itu, Siswati (2010) juga mengungkapkan bahwa hal-hal yang menghalangi minat baca mahasiswa adalah kebiasaan bermain game online dan melihat televisi.

Minat dapat dikatakan sebagai kecenderungan terhadap sesuatu. Kecenderungan mahasiswa dalam membaca secara garis besar dipengaruhi oleh faktor internal dan eksternal. Hal tersebut dipertegas oleh Triatma (2016) faktor-faktor yang mpengaruhi minat baca ada dua, yaitu faktor internal yang meliputi perasaan, perhatian, dan motivasi, sementara itu faktor eksternal terdiri atas peran dosen, lingkungan, dan fasilitas. Dengan demikian, tanpa terpenuhinya faktor-faktor tersebut minat baca mahasiswa tidak akan dapat berkembang dengan baik.Tujuan penelitian ini yaitu: 1) untuk mengetahui faktor-faktor internal dan eksternal yang mempengaruhi minat baca mahasiswa PGSD di Umus; 2) untuk mengetahui faktor-faktor yang mempegaruhi minat baca mahasiswa dari persepsi dosen dan pustakawan. Dengan demikian, penelitian ini sangat perlu untuk dilakukan karena dalam menumbuhkan minat baca mahasiswa perlu memahami faktorfaktor yang mempengaruhinya.

\section{METODE}

Penelitian ini dilaksanakan di Prodi PGSD, Umus tahun ajaran 2018/2019, bulan Juli 2019. Pendekatan penelitian penelitian ini adalah pendekatan kualitatif.
Responden dalam penelitian ini berjumlah 54 dengan perincian: 1) 47 mahasiswa PGSD tahun 2018 yang telah menempuh mata kuliah Konsep Dasar Bahasa Indonesia; 2) 6 dosen 
PGSD; dan 3) 1 pustakawan. Penelitian ini menggali dan mendeskripsikan mengenai: 1) faktor eksternal dan internal yang mempengaruhi kesenangan/minat membaca mahasiswa; 2) faktor lain yang mempengaruhi kesenangan/minat membaca mahasiswa dari persepsi dosen dan pustakwan.

Pengumpulan data dalam penelitian ini menggunakan teknik dokumentasi, observasi, dan angket. Dalam uji keabsahan data, peneliti menggunakan uji kredibilitas yaitu dilakukan dengan memperpanjang pengamatan, meningkatkan ketelitian dan ketekunan, triangulasi, mencocokkan dengan referensi, dan melakukan pengecekan ulang. Analisis data penelitian ini mengacu pada model analisis Miles dan Huberman. Miles Huberman (dalam Sugono, 2017: 246) menyebutkan tiga tahapan dalam model analisis data penelitian kualitatif yang meliputi reduksi data, penyajian data, dan menarik kesimpulan.

\section{PEMBAHASAN}

\section{Faktor Internal yang Mempengaruhi Minat Baca}

a. Faktor Perasaan

Berdasarkan hasil survei yang telah dilakukan terhadap 47 mahasiswa PGSD, terkait hal-hal yang paling disukai, diperoleh data pada gambar

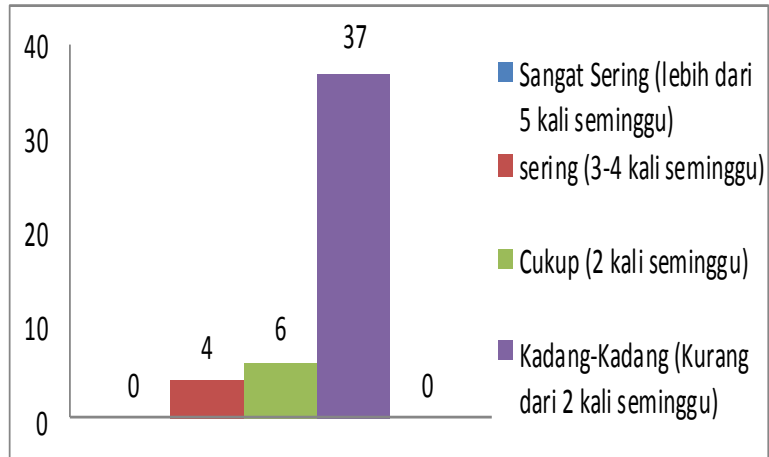

\section{Gambar 1. Kegiatan yang Paling Disukai Mahasiswa}

Aktivitas yang disukai oleh mahasiswa didominasi dengan kegiatan menonton televisi, diikuti kegiatan berselancar di dunia maya, melakukan aktivitas lain, bermain game online, dan membaca buku. Hal ini didukung dari hasil penelitian Siswati (2010) yang menyebutkan bahwa kegiatan membaca menjadi kegiatan yang tidak disukai karena dipengaruhi kemajuan teknologi, selain itu saat ini terdapat beragam hiburan yang lebih menarik tanpa melibatkan media buku.

\section{b. Faktor Perhatian}

Faktor perhatian dilihat dari: 1) alokasi waktu yang disediakan untuk membaca; 2) jenis buku yang disukai mahasiswa; dan 3) tampilan buku. Hasil survei terkait alokasi waktu yang dapat dilihat pada gambar 2 . 


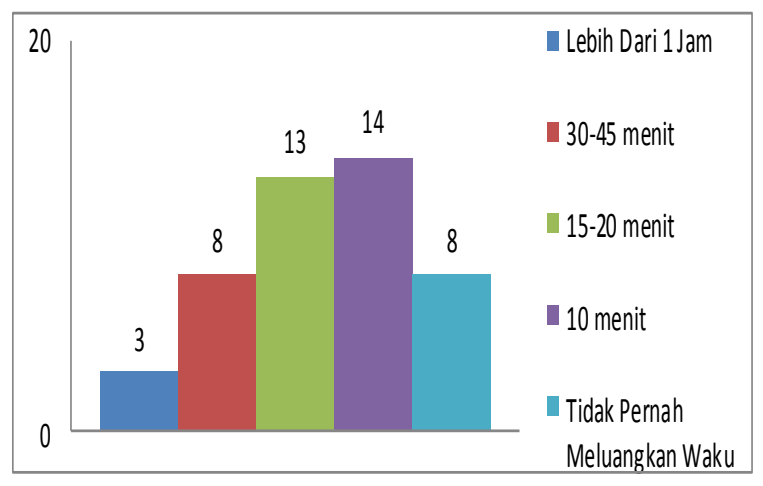

\section{Gambar 2. Waktu yang Diluangkan Mahasiswa untuk Membaca Buku}

Rata-rata mahasiswa hanya sebab itu, mahasiswa hanya akan meluangkan waktu sekitar 10 sampai bertahan sebentar dalam aktivitas 20 menit untuk membaca buku yang tidak dilakukan secara rutin setiap hari. Periyeti (2017) menyebutkan bahwa waktu yang kurang tepat dalam membaca cenderung memunculkan rasa malas untuk membaca. Oleh membaca.

Sementara itu hasil survei yang dilakukan terhadap jenis buku yang disukai mahasiswa diperoleh data pada gambar 3 .

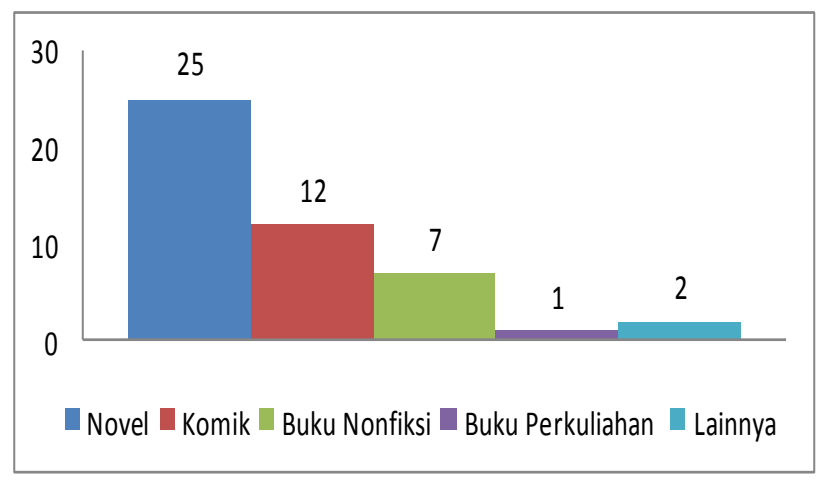

\section{Gambar 3. Jenis Buku yang Disukai Mahasiswa}

Jenis buku yang disukai mahasiswa didominasi dengan buku jenis novel. Hidi (Siswati, 2010) menyebutkan bahwa minat yang sifatnya situasional, misalnya jenis buku yang dibaca akan terintegrasi pengalaman. Hal inilah yang membuat novel lebih disukai dari bahan bacaan yang lainnya.

Terakhir, data hasil survei yang dilakukan terkait tampilan buku, diperoleh data pada gambar 4 . 


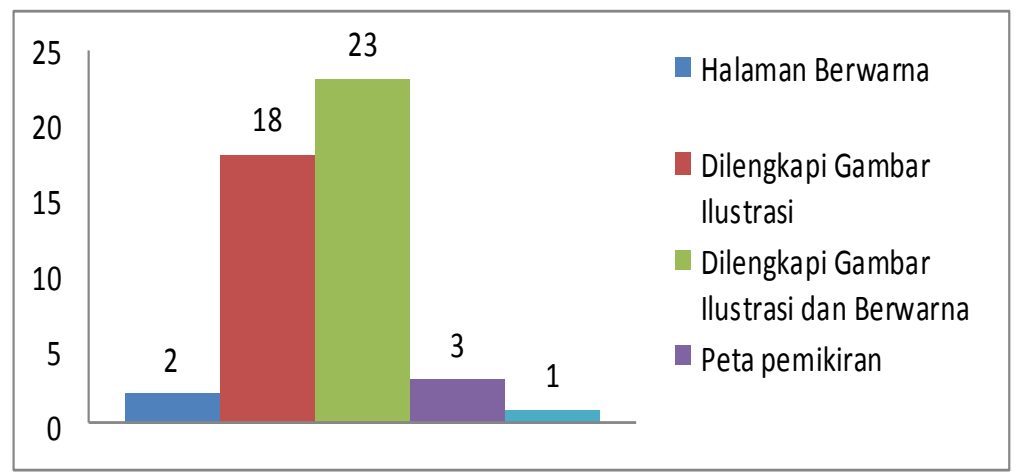

Gambar 4. Tampilan Buku yang Disukai Mahasiswa

Sebagian besar mahasiswa menyukai buku dengan ilustrasi gambar dan buku berwarna yang dilengkapi dengan gambar ilustrasi. Berdasarkan data tersebut dapat dipahami bahwa gaya belajar sebagian besar mahasiswa adalah gaya belajar visual. Papilaya \& Huliselan (2016) gaya belajar visual adalah gaya belajar yang mengandalkan dan menekankan penglihatan, seperti melihat, mengamati, memandang, dalam belajar. Teks yang berisi tulisan bagi orang yang memiliki gaya belajar visual akan sulit untuk dipahami. Oleh sebab itu, tampilan yang menarik dari suatu buku akan sangat mempengaruhi minat baca mahasiswa PGSD di Universitas Muhadi Setiabudi.

\section{c. Faktor Motivasi}

Motivasi atau hal-hal yang mendorong mahasiswa melaksanakan kegiatan membaca mahasiswa dapat dilihat berdasarkan hasil survei yang telah dilakukan.

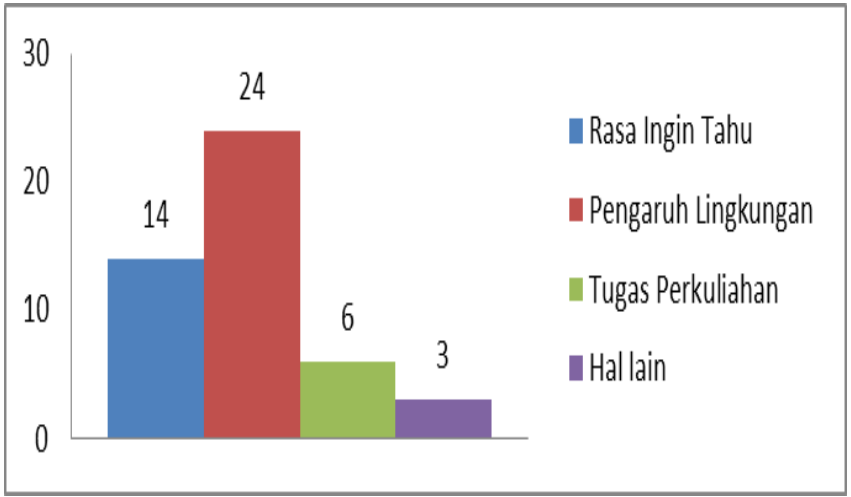

\section{Gambar 5. Motivasi Mahasiswa dalam Membaca Buku}

Sebanyak 14 mahasiswa termotivasi membaca karena rasa ingin tahu, 24 mahasiswa mengatakan karena pengaruh lingkungan, 6 mahasiswa menyebutkan karena tugas perkuliahan, dan 3 mahasiswa menyebutkan ada hal lain yang membuat mereka termotivasi dalam membaca. Rasa ingin tahu merupakan motivasi dari dalam yang mendorong seseorang melakukan aktivitas membaca. Rasa ingin tahu muncul sebagai akibat adanya kebutuhan. Wibawanto (2016) menyebutkan bahwa dengan adanya kebutuhan akan mendorong mahasiswa untuk membaca 


\section{Faktor Eksternal yang Mempengaruhi Minat Baca}

a. Faktor Dosen

Dari 47 mahasiswa yang telah disurvei semua mengaku bahwa tugas yang diberikan oleh dosen telah membuat mahasiswa memaksa diri untuk membaca buku. Tugas merupakan salah satu kebutuan mahasiswa yang harus dipenuhi atau diselesaikan. Wibawanto (2016) menyebutkan bahwa dengan adanya kebutuhan akan mendorong mahasiswa untuk membaca. Seperti halnya tugas yang diberikan oleh dosen, tugas tersebut memaksa mahasiswa membaca untuk dapat menyelesaikannya.

\section{b. Faktor Lingkungan}

Sebanyak 47 mahasiswa mengaku, akan melakukan kegiatan yang banyak dilakukan oleh orangorang yang ada di lingkungannya. Kegiatan membaca misalnya, saat lingkungan keluarga dan masyarakatnya senang membaca, maka mahasiswa jadi ikut terpengaruh untuk membaca. Begitu juga saat orang-orang dilingkungannya melakukan kegiatan lain, mahasiswa akan ikut melakukan kegiatan yang dilakukan oleh orang-orang dilingkungannya. Periyeti (2017) menyebutkan bahwa minat membaca mahasiswa di lingkungan, dipengaruhi oleh lingkungan terdekatnya seperti keluarga, sekolah, serta masyarakat.
Mahasiswa akan cenderung mengikuti aktivitas yang kebanyakan dilakukan oleh orang-orang yang ada dilingkungannya. Jika lingkungannya suka membaca, maka mahasiswa juga akan cenderung mengikutinya.

Hasil survei menunjukkan hanya 10 mahasiswa yang mengaku lingkungan keluarganya yang suka membaca, 37 mahasiswa sisanya mengaku lingkungan mereka tidak suka membaca. Kegiatan sehari-hari seperti ke sawah, pekerjaan rumah, dll dikatakan oleh mahasiswa lebih mendominasi dari pada kegiatan membaca. Sementara itu dari 10 orang mahasiswa yang lingkungannya, 7 orang mengaku suka membaca mengaku ikut membaca koran atau majalah di rumah yang dibaca anggota keluarganya. Kemudian tiga dari sepuluh orang tersebut mengaku, hanya akan membaca majalah/koran yang dibaca anggota keluarga pada poin yang diminati saja.

\section{c. Faktor Fasilitas}

Faktor fasilitas yang dapat mempengaruhi minat membaca mahasiswa adalah perpustakaan. Berikut adalah data rata-rata mahasiswa mengunjungi perpustakaan dalam setiap minggu yang didasarkan dari pengakuan mahasiswa. 


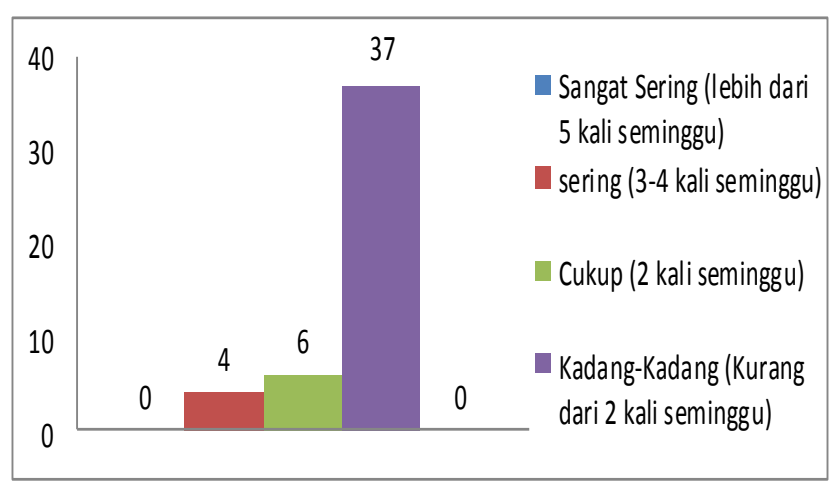

\section{Gambar 6. Rata-Rata Mahasiswa Mengunjungi Perpustakaan}

Sebagian besar mahasiswa (sebanyak 37 dari 47 total mahasiswa yang disurvei menjawab kadangkadang mereka mengunjungi perpustakaan. Sisanya, sebanyak 4 mahasiswa menjawab sering, dan 6 mahasiswa lainnya menjawab cukup. Putri \& Suyitno (2018) mengemukakan tingkat kunjungan mahasiswa ke perpustakaan dapat menunjukkan minat baca mahasiswa. Tingkat kunjungan mahasiswa ke perpustakan dipengaruhi oleh faktor ketersediaan buku yang dicari, kebutuhan mahasiswa, dan kondisi lingkungan perpustakaan. Saat ditelusur lebih jauh terdapat beberapa hal yang menyebabkan mahasiswa jarang ke perpustakaan, diantaranya belum merasa butuh dan ketidaktersediaan referensi yang dibutuhkan.

\section{Faktor-Faktor yang Mempengaruhi Minat Baca Ditinjau dari Persepsi Dosen dan Pustakawan}

Dari 6 orang dosen yang telah diwawancara, dapat diketahui bahwa minat membaca mahasiswa dipengaruhi oleh: 1) rasa ingin tahu; 2) topik yang diminati; dan 3) ketersediaan buku. Wibawanto (2016) menyebutkan rasa ingin tahu dan topik yang diminati akan mendorong mahasiswa menggali informasi dari berbagai sumber, termasuk dari buku. Oleh sebab itu, rasa ingin tahu dan topik yang diminati menjadi pendorong pembaca untuk membaca dan memahami isi buku secara tuntas.

Disamping rasa ingin tahu dan topik yang diminati, ketersediaan buku juga mempengaruhi minat membaca mahasiswa. Triatma (2016) menegaskan bahwa ketersediaan buku yang cukup memadai dapat menarik tumbuhnya minat baca. Seringkali saat mahasiswa kesulitan mencari buku di perpustakaan, mahasiswa akan mengurungkan niatnya untuk membaca buku.

Selain dosen, pustakawan adalah orang yang mengetahui secara langsung faktor yang mempengaruhi minat membaca mahasiswa disuatu kampus. Faktor yang paling besar dalam mempengaruhi minat membaca mahasiswa menurut pustakawan adalah faktor tugas dari dosen. Lebih lanjut menurut pustakawan, tidak semua tugas dapat mempengaruhi minat baca mahasiswa. Tugas-tugas yang dapat memberikan pengaruh terhadap minat membaca mahawsisa adalah tugas yang berbentuk mini riset. Tugas berbentuk riset akan menuntut mahasiswa memahami konsep, sehingga mengharuskan mahasiswa membaca buku 


\section{SIMPULAN}

Kesimpulan hasil penelitian ini yaitu: 1) faktor-faktor interen yang mempengaruhi minat membaca mahasiswa meliputi perasaan, perhatian, dan motivasi; 2) faktorfaktor eksteren yang mempengaruhi minat membaca mahasiswa meliputi dosen, lingkungan, dan fasilitas; 3) dari persepsi dosen dan pustakawan, faktor-faktor yang mempengaruhi minat membaca mahasiswa meliputi rasa ingin tahu, topik yang diminati, ketersediaan buku, dan tugas.

Saran yang dapat dituliskan
yaitu: 1) mahasiswa dapat
mendongkrak minat bacanya dengan
mengawali membaca buku-buku yang
disukai, seperti novel; 2) dosen perlu
memberikan tugas yang menuntut
mahasiswa membaca buku
diantaranya resensi, bedah jurnal, dan
mini riset; 3) dalam hal pengadaan
buku, pusktakawan perlu melibatkan
mahasiswa secara langsung, dengan
harapan dapat mencukupi
ketersediaan buku yang dibutuhkan
oleh mahasiswa.

\section{DAFTAR PUSTAKA}

Amiranti, CC. (2017). Minat Baca Anak Rendah, Perlu Terobosan Baru.

http://amp.kompas.com/lifestyle/ diunduh tanggal 28 Oktober 2019, Pukul 13.03

Djuanda, D., Resmini, N., Indihadi, D. (2006). Pembinaan dan Pengembangan Pembelajaran Bahasa dan Sastra Indonesia. Bandung: Upi Press

Papilaya, JO \& Huliselan, N. (2016). Identifikasi Gaya Belajar Mahasiswa. Jurnal Psikologi Undip, Vol. 15, No. 1, Pg. 56-62

Patiung, D. (2016). Membaca Sebagai Sumber Pengembangan Intelektual. Jurnal Al-Daulah. Vol. 5, No. 2, Pg. 352-376

Priyeti. (2017). Usaha Meningkatkan Minat Baca Mahasiswa. Jurnal Pustaka Budaya. Vol. 06, No. 1, Pg. 55-67

Putri, ADS \& Suyitno. (2018). Analisis Minat Baca Mahasiswa Semester V di PGSD UPGRIS. Jurnal Widya Wacana. Vol. 12, No. 2, Pg. 9-17
Siswati. (2010). Minat Membaca Pada Mahasiswa (Studi Deskriptif pada Mahasiswa Fakultas Psikologi UNDIP Semester I). Jurnal Psikologi Undip. Vol. 8, No. 2, Pg. 124-134

Sugiono. (2011). Metode Penelitian Pendidikan Pendekatan Kuantitatif, Kualitatif, dan R\&D. Bandung: Alfabeta

Taufina. (2016). Mozaik Keterampilan Berbahasa di Sekolah Dasar.Bandung: Angkasa

Tirto Online. (2017). Najwa Paparkan Data Soal Rendahnya Minat Baca Indonesia. https://irto.id/najwa-paparkandata-soal-rendahnya-minatbaca-indonesia-cupM, diunduh tanggal 25 Maret 2019, pukul 12.39

Triatma, IN. (2016). Minat Baca Pada Siswa Kelas VI Sekolah Dasar Negeri Delegan 2 Prambanan Sleman Yogyakarta. Jurnal Teknologi Pendidikan. Vol. 5, No. 6, Pg. 166-178 
Wibawanto, A. (2016). Menumbuhkan Minat Baca dan Tulis Mahasiswa. Jurnal Pustakaloka.

Vol. 5, No. 1, Pg. 125-134 